Cahiers $d u$ MONDE RUSSE

\section{Cahiers du monde russe}

Russie - Empire russe - Union soviétique et États indépendants

$46 / 1-2 \mid 2005$

La Russie vers 1550

\title{
ФЛОРЕНТИЙСКАЯ УНИЯ И АВТОКЕФАЛИЯ МОСКОЙ ЦЕРКВИ
}

Valerij E. ZEMA

\section{OpenEdition \\ Journals}

Édition électronique

URL : https://journals.openedition.org/monderusse/8814

DOI : 10.4000/monderusse.8814

ISSN : $1777-5388$

Éditeur

Éditions de l'EHESS

Édition imprimée

Date de publication : 1 janvier 2005

Pagination : 397-410

ISBN : 2-7132-2055-6

ISSN : $1252-6576$

Référence électronique

Valerij E. ZEMA, « Флорентийская уния и автокефалия Моской церкви », Cahiers du monde russe [En ligne], 46/1-2 | 2005, mis en ligne le 01 janvier 2007, consulté le 02 septembre 2022. URL : http:// journals.openedition.org/monderusse/8814; DOI : https://doi.org/10.4000/monderusse.8814 
chercher : repérer : avancer

Cet article est disponible en ligne à l'adresse :

http://www.cairn.info/article.php?ID REVUE=CMR\&ID NUMPUBLIE=CMR 461\&ID ARTICLE=CMR 4610397

\title{
Флорентийская уния и автокефалия Моской церкви
}

\author{
par Valerij E. ZEMA
}

\section{| Editions de l'EHESS | Cahiers du monde russe}

\section{5/1-2 - Vol 46}

ISSN 1252-6576 | ISBN 2713220556 | pages 397 à 410

Pour citer cet article :

- E. ZEMA V., Cahiers du monde russe 2005/1-2, Vol 46, p. 397-410.

Distribution électronique Cairn pour les Editions de l'EHESS.

(C) Editions de l'EHESS. Tous droits réservés pour tous pays.

La reproduction ou représentation de cet article, notamment par photocopie, n'est autorisée que dans les limites des conditions générales d'utilisation du site ou, le cas échéant, des conditions générales de la licence souscrite par votre établissement. Toute autre reproduction ou représentation, en tout ou partie, sous quelque forme et de quelque manière que ce soit, est interdite sauf accord préalable et écrit de l'éditeur, en dehors des cas prévus par la législation en vigueur en France. Il est précisé que son stockage dans une base de données est également interdit. 


\title{
ФЛОРЕНТИЙСКАЯ УНИЯ \\ И АВТОКЕФАЛИЯ МОСКОВСКОЙ ЦЕРКВИ
}

\author{
Некоторые наблюдения \\ над нарративными источниками
}

\begin{abstract}
Ферраро-Флорентийский собор (1438-1439 гг.) был одной из попыток преодоления раскола некогда единой христианской Церкви. Несмотря на неудачу попыток осуществления унионных договоренностей на местах, проведение собора и достигнутое на нем согласие еще несколько столетий оказывало влияние на восточное христианство. На украинских и белорусских землях Брестская уния (1595-1596 гг.) трактовалась в свете преемственности и продолжения предшествовавшего унийного процесса. Обращение к юридическому и историческому прецеденту соглашений во Флоренции послужило причиной полемики между разными сторонами (католиками, православными и православными, объединенными с Римом), поисков и публикации исторических источников, которые могли бы отразить связь Киевской митрополии с Апостольской столицей. Несколько иное значение уния имела для Великого княжества Московского. Негативные и, подчас, легендарные описания собора и его решений на территории восточной Европы имели большое значение для легитимизации автокефальной Московской митрополии ${ }^{1}$.

Среди источников, которые обращаются к истории унии - сообщения о соборе в летописях, повести-хождения, актовые источники, носящие, возможно, апокрифический характер. Целью антифлорентийских
\end{abstract}

1. Иоанн Мейендорф обращает внимание на то, что титул «Киевский» был опущен из титулатуры «митрополитов всея Руси» с резиденцией в Москве. См.: И. Ф. Мейендорф, «Флорентийский собор: причины исторической неудачи», Из истории русской культуры, т. II, кн. 1, М., 2002, с. 413. 
памфлетов, как отмечает Андрей Плигузов, было противопоставление греческих патриархов и императора, которые пошли на соглашение с Римской курией, православному и «благочестивому» московскому князю. В связи с полным завоеванием территории Восточной Римской империи, в Московии греческий восток был провозглашен в 1459 году «изрушившимся», а новосозданная митрополия попала в тесную зависимость от великокняжеского двора ${ }^{2}$. Задачей нашего небольшого исследования является изучение комплекса антифлорентийских текстов, а именно моделирование московскими книжниками того, что должно было получить оценку «негативного» (проведение собора, сторонники унии) и «позитивного» (московское православие, великий князь Василий Васильевич). Изучение рецепции Флорентийской унии в Восточной Европе имеет достаточно продолжительную историю, которая знала как издание источников, так и их исследование. Мы сосредоточимся на источниках, отражавших негативное восприятие унии ${ }^{3}$.

Поскольку обозрение канона российской историографии было сделано ранее ${ }^{4}$ мы подробнее остановимся на публикациях последних лет. Отметим, что весь комплекс антифлорентийских нарративов принято делить на две редакции, каждая из которых имеет соответственно два вида. Первый вид первой редакции, - «Повесть Симеона Суздальского об осьмом соборе» 5 (далее - ПСС), созданная, как считал Лев Черепнин, около 1447 г. ${ }^{6}$ Ученый выделил в ПСС пять структурных частей: рассказ автора об истории создания этого текста, описание собора в Ферраре и Флоренции, рассказ о возвращении Симеона на территорию Киевской митрополии, рассказ о приезде митрополита Исидора в Москву и отказе великого князя Василия Васильевича принять унию, панегирик московскому князю - хранителю православия ${ }^{7}$. Второй вид первой редакции «Инока Симеона иерея Суждальца повесть, како римский папа Евгений состави осмый собор» ${ }^{8}$

2. А. Плигузов, «От Флорентийской унии к автокефалии Русской Церкви», Harvard Ukrainian Studies, vol. XIX, 1995: Essays presented to Edward L. Keenan on his Sixtieth Birthday by his Colleagues and Students, p. 514-515.

3. Источники, описывающие путешествия на собор - перегринации - изучали Николай Новиков, Александр Щербина, Иван Сахаров и Наталья Казакова. См.: А. Д. Щербина, Литературная история русских сказаний о Флорентийской унии, Одесса, 1902; Н. А. Казакова, Западная Европа в русской письменности XV-XVI веков, под ред. Д. С. Лихачева, Л., 1980.

4. Н. Ф. Дробленкова, «Симеон Суздальский», СККДР, Вып. 2: Вторая половина XIV-XVI в., ч. 2, Л., Наука, 1989, с. 334-336; Она же, «Слово избрано от святых писаний, еже на латыню», там же, с. 401-403.

5. «Повесть Симеона Суздальскаго объ осьмомъ соборе», в: А. С. Павлов, Критические опыты по истории древнейщей греко-русской полемике против латинян, СПб., 1878, с. 198-210.

6. Л. В. Черепнин, «К вопросу о русских источниках по истории Флорентийской унии», Средние века, вып. 25, 1964, с. 176-187.

7. Там же, с. 177.

8. «Инока Симеона иерея Суждальцу повесть како римский папа Евгений состави Осмый соборъ своими единомышленники», в: А. Попов, Историко-литературный 
(далее - ИСС) был лишен черт индивидуальности «автора», присущих предыдущему варианту. От двух выше названых версий значительно отличается вторая редакция, первый вид которой, - «Слово избрано от святых писаний, еже на латыню» ${ }^{9}$, а второй - летописная версия, которая фиксируется с конца XV века.

Среди новых работ, посвященных изучению источников, связанных с восприятием унии в Восточной Европе, - статья Андрея Плигузова, в которой рассматривается как комплекс антиунийных нарративов, так и актовые источники, возникшие в связи с Вселенским собором, в том числе, как считает автор, апокрифического характера ${ }^{10}$. Восприятие унии и митрополита Исидора в Новгороде изучали Владимир Водов и А. Г. Бобров. Первый исследователь пришел к выводу, что негативное восприятие унии появилось через несколько лет после проведения собора и возвращения Исидора на территорию Киевской митрополии. Отрицательное отношение к унии формируется в 50-х гг. XV в., когда в Литве развернул свою деятельность ученик Исидора Григорий, провозгласивший себя митрополитом и посягнувший таким образом на юрисдикцию митрополичьей кафедры, занимаемой в Москве рязанским епископом Ионой. Отрицательное отношение к Исидору в Новгороде, как предполагает Водов, сформировалось в связи с нанесением Исидором ущерба местной церковной казне при отъезде на собор, когда митрополит поставил в Пскове независимого от Новгорода архиепископа Геласия, что ограничило поступление средств в центр бывшей aрхиепископии $^{11}$. А. Г. Бобров показывает, что созданию псковской архиепископии предшествовала подготовительная работа. Решение митрополита вывести Псков из подчинения Новгорода, считает исследователь, едва ли можно объяснить лишь корыстолюбивыми соображениями либо изменением в московско-новгородских отношениях, простым перераспределением церковных доходов. Перед Исидором стояла более важная задача - объединение христианского мира ${ }^{12}$. Причины же неприятия унии после возвращения Исидора следует искать не в конфессиональных разногласиях, но в политических соглашениях, достигнутых перед приездом Исидора в Москву. Война Москвы, Пскова и Твери против Новгорода зимой 1440/1441 г., как считает исследователь, свидетельствует о поддержке митрополита Исидора инициаторами этих военных действий. Евфимий II, в противовес сторонникам унии,

обзор древнерусских полемических сочинений против латинян: XI-XV вв., М., 1875 c. 344-359.

9. «Слово избрано от святых писаний еже на латыню», в: А. Попов, Историколитературный обзор..., с. 360-395.

10. А. Плигузов, указ. соч., с. 513-530.

11. В. А. Водов, «Новгород и Флорентийская уния», Восточная Европа в исторической перспективе. К 80-летию В. Т. Пашуто, М., Языки русской культуры, 1999, с. 42-46.

12. А. Г. Бобров, Новгородские летописи XV века, СПб., Дмитрий Буланин, 2001, c. 195 . 
инициировал создание культа новгородских святых и «старины», а «папскому золоту» противопоставил значительные средства новгородской казны во время заключения Демонского мира, накануне возвращения митрополита с собора ${ }^{13}$. Вывод: политическая победа новгородского архиепископа над митрополитом предопределила судьбу Флорентийской унии и заложила фундамент автокефалии Московской церкви ${ }^{14}$.

Основательно проанализировал нарративные источники, связанные с восприятием Флорентийской унии в Восточной Европе, Яков Лурье 15 . Ученый подверг анализу сообщения о поездке рязанского епископа Ионы в Константинополь (для рукоположения на Киевскую митрополию) еще до Флорентийского собора. Во время этой поездки Иону опередил Исидор, поэтому митрополия была обещана рязанскому епископу только после смерти рукоположенного. Соотвественно, избрание Ионы вместо «изменника» Исидора представлялось как закономерное решение. Сообщения о визите Ионы в Константинополь рассматривались Лурье как апокрифы, тем более что в летописных версиях, синхронных времени унии и создания автокефальной митрополии, они отсутствуют. Утверждение об апокрифичности информации о визите Ионы в Константинополь, казалось бы, уже стало историографическим каноном. Впервые в нарративных источниках сообщения о поездке рязанского епископа фиксируются в Степенной книге царского родословия, составитель которой также опирался на Великие Четьи Минеи, где было помещено житие Ионы ${ }^{16}$. О предварительном наречении Ионы на митрополию свидетельствуют также актовые документы, среди которых - грамота 1441-1443 г. в своде 1518 г. и в Кирилло-Белозерском сборнике №11/1088, датированного 90-ми гг. XV в. Сомнения в достоверности этого источника высказал еще А. Циглер, который также обратил внимание на связь между грамотой и «Словом избранным от святых писаний еже на латыню» (далее - СИЛ) ${ }^{17}$. Скорректировать информацию о достоверности поездки Ионы в Константинополь предложил Андрей Плигузов. Вновь опубликованное им «Послание от Ионы митрополита к князю Александру Володимировичу на Киев» содержит рассказ о поездке рязанского епископа в Константинополь еще перед заключением Флорентийской унии, и о том, что его упредил Исидор. Плигузов предлагает датировать составление этой грамоты между декабрем 1449 г. и ноябрём 1450 г., что говорит о реальности осуществления

13. Там же, с. 212-213.

14. Там же, с. 214.

15. Я. С. Лурье, «Как установилась автокефалия Русской Церкви в XV в.?», ВИД, вып. XXIII: XVIII Международный конгресс византинистов, Л., Наука, 1991, с. 181-198; Он же, Две истории Руси XV века. Ранние и поздние, независимые и официальные летописи об образовании Московского государства, СПб., Дмитрий Буланин, 1994.

16. Я. С. Лурье, Две истории Руси XV века..., с. 93-100.

17. Там же, с. 101-102. 
поездки ${ }^{18}$. В свою очередь Сергей Кистерев, рассмотрев летописи, синхронные времени правления Ионы, пришёл к выводу, что их молчание о визите в Константинополь рязанского владыки не могут рассматриваться в качестве контраргумента ${ }^{19}$. Исследователь опровергает утверждение, что изменения в титулатуре московского правителя в пользу ее наращивания «великий князь всея Руси» - может рассматриваться как довод, подтверждающий апокрифичность грамот. Такое изменение, как показывет Кистерев, прослеживается уже в середине XV в. ${ }^{20}$ Предположения о том, что поездка в Константинополь была позднейшей выдумкой возникли, по мнению Кистерева, на основании сомнений законности занятия митрополии Ионой:

в русском обществе было немалое число неуверенных в праве Ионы на занятие митрополичьего престола без санкции патриарха. Именно отражением повышенного интереса к этому вопросу является включение текстов официальных документов в великокняжеской канцелярии в состав летописного свода. Однако, нет оснований полагать, будто сомневающиеся в правах Ионы сомневались в реальности его поездки в Константинополь ${ }^{21}$.

Позволим себе перенестись на несколько десятилетий назад от времен унии и избрания Ионы, обратив внимание на «Ставленную грамоту» иного «сомнительного» митрополита, Григория Цамблака. В отличии от ситуации с Ионой, Цамблак был поддержан украинско-белорусской частью Киевской митрополии на соборе в Новогрудке (1415 г.). «Ставленная грамота», подтверждающая избрание Цамблака, хорошо известна в литературе и зафиксирована также в летописных списках ${ }^{22}$. Мы же обратим внимание на то, что между «Посланием Ионы» (и аргументацией антифлорентийского комплекса в целом) и «ставленной грамотою» Цамблака обнаруживаются некоторые параллели, фиксирующиеся также в позднейших антиунийных текстах. И грамота, и антифлорентийский комплекс, прежде всего, близки по духу: в обоих случаях главной темой было оправдание выбора

18. A. I. Pliguzov, «An Attempt at a Commentary: Two Proposed Texts for Future Publication», Russian History / Histoire Russe, vol. 29, No. 1, Spring 2002, p. 5, 11.

19. С. Н. Кистерев, «Источники о пребывании рязанского епископа Ионы в Константинополе», Россия и Христианский Восток, вып. II-III, М., Индрик, 2004, c. $59-60,64-65$

20. С. Н. Кистерев, «"Великий князь всея Руси" в XI-XV веке», Очерки феодальной России, вып. 6, М., УРСС, 2002, с. 47-85.

21. С. Н. Кистерев, «Источники о пребывании рязанского епископа Ионы в Константинополе», Россия и Христианский Восток, с. 68.

22. Перечень списков грамот и её текст напечатан в: «Памятники древне-русского канонического права», ч. I: «Памятники XI-XV вв.», РИБ, т. 6, СПб., 1880, с. 309 314. Следует добавить еще один список XVI в. в сборнике из коллекции Петра Овчинникова в НИОР РГБ, ф. 209, ед. хр. 789. Языковые особенности и присутствие Жития Ефорсинии Полоцкой указывают на белорусское происхождение рукописи. См. также: А. И. Яцимирский, Григорий Цамблак: Очерк его жизни, административной и книжной деятельности, СПб., 1904, с. 180; Fr. J. Thomson, «Gregory Tsamblak - the Man and Myth», Slavica Gandensia, vol. 25, 1998, p. 66-69. 
митрополита, каноничность которого была весьма сомнительной в глазах современников. Общим в двух случаях была апеляция к апостольскому правилу избрания первосвятителей, а также прецедент избрания при Изяславе (1147 г.) митрополитом Климента Смолятича.

Примечателен также подбор аргументов в пользу правомочности избрания этих митрополитов. В отличии от священной миссии Василия Васильевича, для Великого княжества Литовского важным было покровительство правителя-католика. Аргументом для составителей «ставленной грамоты» служит то, что размеры и население ВКЛ значительно превышает Сербию и Болгарию, где были подобные прецеденты избрания митрополитов. Среди аргументов - факты симонии, зависимость Константинопольской патриархии от светской власти. Сличение ставленной грамоты с антифлорентийскими текстами оставим для будущего исследования, вернувшись ко времени восприятия Флорентийской унии в Московии.

Я. Лурье определяет время написания ПСС 1461-1462 гг., т.е. временем составления СИЛ ${ }^{23}$. Исследователь указывает также, что на избрание Ионы митрополитом великий князь Василий Васильевич дал согласие только в декабре 1448 г., т.е. значительно позже событий собора; в процессе элекции не участвовали главы Церкви двух независимых земель - Новгорода и Твери ${ }^{24}$.

Исследуя источники, связанные с именем митрополита Ионы, О. Абеленцева обратила внимание на его послание к литовским епископам ${ }^{25}$. Относительно второй части послания, в которой рассказывается о приходе Григория Болгарина, ставленника римской курии, а также о ФеррароФлорентийском соборе, исследовательница указала на текстологические параллели между посланием Ионы и Московским летописным сводом конца $\mathrm{XV}$ в., то есть автор пользовался сводом для составления послания. Речь идет о прочтении Исидором во время службы в Москве грамоты римского папы о воссоединении Церквей, а также фрагменте, в котором говорится о бегстве Исидора и Григория Болгарина, - приверженцев «латинских ересей». Далее Абеленцева делает вывод, что наличие этих фрагментов в Московском летописном своде предполагает их существование также в «Повести о восьмом соборе» Симеона Суздальского, поэтому ПСС была источником для составления послания, известного под авторством митрополита Ионы ${ }^{26}$. Сравнение двух вышеуказанных фрагментов послания с двумя видами первой

23. Я. С. Лурье, Две истории Руси ХV века..., с. 106-107.

24. Там же, с. 108.

25. О. А. Абеленцева, «О датировке и некоторых особенностях содержания послания митрополита Ионы литовским епископам (РИБ, № 87), Опыты по источниковедению», Древнерусская книжность: редактор и текст, отв. ред. Ю. Г. Алексеев, В. К. Зибров, вып. 3, СПб., Дмитрий Буланин, 2000, с. 7-15. Выражаю признательность Алексею Сиренову, участнику школы, за возможность ознакомится с публикациями сборника.

26. Там же, с. 11-12. 
редакции антифлорентийских текстов, связанных с именем Симеона Суздальского, опровергает утверждение исследовательницы. Более того, указанные фрагменты из послания Ионы имеют непосредственные (практически дословные) параллели не с Московским сводом конца XV в., как указывала Абеленцева, а с СИЛ, - первым видом второй редакции антифлорентийских текстов (по традиционной классификации) $)^{27}$ В дальнейшем О. Абеленцева продолжила изучать флорентийскую традицию на востоке Европы, исследуя представительство Твери во время проведения объединительного собора ${ }^{28}$.

Гипотезой нашего исследования является предположение о том, что антифлорентийский комплекс возник позже времени заключения унии и последующих событий в Киевской митрополии, был расширен благодаря привлечению текстов «параллельного чтения» и собственных привнесений авторов, и не утратил своей популярности до времени создания Московского патриархата. Нарративные источники, отражающие якобы негативное восприятие собора в Восточной Европе, были составлены в связи с необходимостью подтверждения легитимности и правомочности новой митрополии. Для конструирования такой модели книжники использовали «тексты параллельного чтения», т.е. источники полемического содержания, связанные также с расколом Церкви 1054 г. Мы попробуем воссоздать генеалогию антифлорентийских памфлетов, предложив собственную гипотетическую стемму. Для этого обратимся к уже названным выше источникам, которые принято делить на две редакции.

Текстологическое сравнение ПСС и ИСС показывает, что эти два вида первой редакции, как принято их классифицировать, значительно отличаются только во вступительной части. ПСС начинается рассказом о составе участников собора. Автор (Симеон Суздальский) замечает, что он с самого начала не хотел принимать участия в соборе, поэтому, обратившись за благословением к Марку Эфесскому, покинул Венецию и дошел до Новгорода, где рассказал о заключении унии. В конце автор сетует, что «зло» (т.е. собор), произошло из-за алчности греков; в Москве же утвердилось православие «христолюбивым великим князем Василием Васильевичем». В версии, содержащейся в ИСС вина за проведение собора перекладывается на понтифика Евгения, который пообещал «золото» императору Иоанну Калуяну и патриарху Иосифу, а также помощь в обороне Константинополя, что привлекло их на сторону папы. Написав великому князю «всея Руси» Василию Васильевичу послание, император и патриарх попросили прислать на собор Исидора, «родом латынянина». Князь ответил на это, что собор не отвечает церковным канонам, а Исидор сообщил Василию Васильевичу, что будет принимать участие в соборе

27. См.: «Слово избрано от святых писаний еже на латыню», с. 376, 378.

28. О. А. Абеленцева, «Охранная грамота папы Евгения IV послу русскому Фоме: О тверском посольстве на Ферраро-Флорентийский собор», Российское государство в XIV-XVII вв.: Сборник статей, посвященных 75-летию со дня рождения Ю.Г. Алексеева, СПб., Дмитрий Буланин, 2002, с. 40-47. 
только для утверждения православия. От сообщений о Симеоне, фиксирующихся в ПСС, в ИСС сохранилось лишь сообщение о том, что автор записал прения с папой. Во вступительной части второго вида (ИСС) подчеркивается алчность греков, мудрость Василия Васильевича, в титулатуре которого добавляется «всея Руси». Продолжают тексты обеих версий сообщения о процедуре собора. В ИСС интерполируется фрагмент о торжественном вхождении папы в помещение, где проводился собор, а также то, что император и патриарх сидели около понтифика во время прений ${ }^{29}$. После оглашения обращения к участникам собора Марка Эфесского (его фигуре придается значение во всех текстах антифлорентийского характера), сообщения в обеих версиях начинают расходиться. Тем не менее, содержание их может быть резюмировано следующим образом: следует отказаться от богатства, предлагаемого папой, и возвращаться домой, сохранив верность семи Вселенским соборам. В этих текстах подчеркивается характерный для антифлорентийских памфлетов тезис об алчности греков; рассказывается также о смерти приверженцев унии. Среди них - «философ Иван», выступивший против Марка Эфесского, флорентийский «архимандрит Амвросий», предлагавший золото Марку. В обеих версиях титулатура московского правителя была подвергнута «обновлению»: в ПСС - «великий князь Василий Васильевич, белый царь всеа Руси» (имеет непосредственную параллель с Ордынской титулатурой $^{30}$ ), в ИСС - «великий князь Василий Васильевич всеа Руси». Сокращенная версия рассказа об участии представителей Киевской митрополии присутствует также в третьей Пахомиевой редакции «Жития Сергия Радонежского» (далее - ЖСР) ${ }^{31}$, которую Борис Клосс датирует 1442 г. $^{32}$ Текст памятника имеет непосредственные параллели с двумя выше рассмотренными версиями, сообщая также о судьбе Симеона Суздальского, что позволяет включить его в гипотетическую семью $\beta$ (vide: Stemma codicum). Если в ЖСР напоминание о каноническом запрещении проведения собора звучит из уст Марка Эфесского, то в ПСС и ИСС она вложена в уста великого князя. Текстологическое влияние ЖСР прослеживается также в летописной версии антифлорентийских текстов.

Известно две версии ПСС. Первую из них Павлов издал по двум спискам: (1) рукопись из собрания Московского публичного музея; (2) по рукописи Архива Министерства иностранных дел. В Холмогорской летописи, созданной в средине XVI в. ${ }^{33}$, как нам удалось установить, содержится иная версия ПСС. Несмотря на то, что между двумя версиями фиксируются

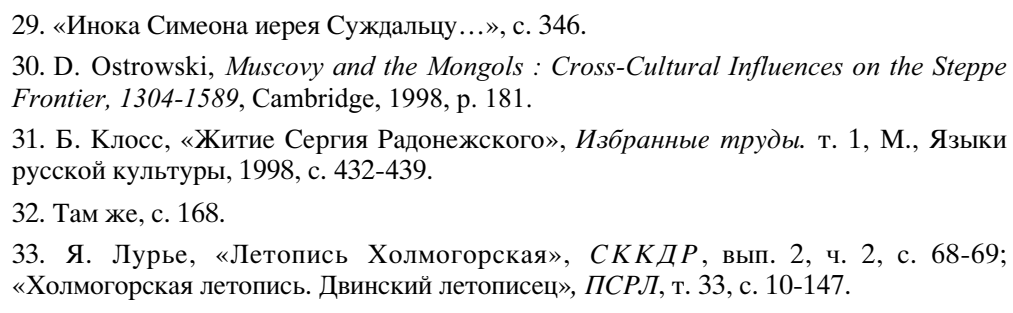


минимальные текстологические разночтения, сравнение ПСС в Холмогорской летописи и Архивном списке показывает их близость. Относительно ИСС, то этот текст, будучи близким ПСС Архивной, имеет также некоторые лексические и смысловые параллели с Холмогорской версией, отсутствующие в ПСС $^{34}$. Можно сделать предположение, что создатель ИСС пользовался двумя версиями текстов, близкими к Холмогорскому и Архивному.

Значительно отличается от всех рассмотренных выше версий антифлорентийский памфлет СИЛ ${ }^{35}$. По сравнению с версиями ИСС и ПСС в нем фиксируются значительные текстуальные перемещения и интерполяции: выезжавшего на собор Исидора великий князь напутствует напоминанием о необходимости настоящего соединения церквей (т.е. отказ католиков от догматических и обрядовых различий с православными), приводится факт преклонения митрополита перед латинским крестом, подчеркивается более высокий статус православия Московии. Исидор прибывает на собор как представитель «великого царя» Василия Васильевича. Изменяется проповедь Марка Эфесского, обращенная к восточным представителям на соборе: иерарх обещает проклятие всем, кто при церковном поминании будет ставить папу на первом месте. Из текста выведен Симеон Суздальский, который известен нам из всех предыдущих версий. Заключительная часть собора передана коротко. Среди существенных интерполяций - осуждение греческих представителей, принимающих участие в соборе и самого митрополита Исидора; автор обращается к благочестивой истории Константинополя, вспоминает князя Владимира, который нашел там «настоящую веру» 36 .

Следует отметить и влияние ранних полемических текстов: сообщения о бритье бород и усов служителями церкви, охота с собаками. В текст СИЛ помещено также обращение митрополита Исидора к своей пастве, послание папы Евгения великому князю. Василий Васильевич сравнивается с новым Владимиром и новым Константином. Именно он «узнал» в митрополите «еретика» и потребовал от него покаяния, но Исидор убежал со своим учеником Григорием в Рим. Князь не предпринял попыток вернуть «изменника», либо применить апостольское правило (сомнительного происхождения), по которому «еретика» должны были сжечь на костре или закопать живьем в землю. Рассказывается также о том, что великий князь, заботясь о церкви, оставшейся без пастыря, собрал архиепископов, священников, философов и риторов, которые должны были искать в священных писаниях запрещения на созыв восьмого собора, а также возможность избрать митрополита для «земли просиявшего благочестия». Среди используемых для создания СИЛ памятников ранней антилатинской

\footnotetext{
34. Ср.: «Повесть Симеона Суздальского объ осьмомъ соборе», с. 202; «Холмогорская летопись...», с. 101; «Инока Симеона иерея Суждальцу...», с. 346.

35. См. примеч. 9.

36. Там же, с. 372-373.
} 
полемики - «Повесть о латынех, когда отлучишас от грек» ${ }^{37}$ - апокриф, рассказывающий о приходе в Рим императора Калуяна, который принес filioque и опресноки. Текст цитируется не полностью, с незначительными перестановками и интерполяциями. Следующим текстом «параллельного чтения» является «Никиты мниха и презвутера монастыря Стоудинскаго пореклом стифита» ${ }^{38}$, а также письмо Михаила Керулария (incip.: Сотворяют оубо жидовствующие сут сия... $)^{39}$. Используется также «Повесть о латынех» при рассказе о том, как православные «аламаны» стали «латинниками». Продолжением практики использования актовых источников является включение письма короля Казимира великому князю с просьбой принять на митрополию Григория Болгарина и негативный ответ князя. В конце помещена похвала наследникам Василия Васильевича князьям Ивану, Георгию и Андрею. Вспоминается также митрополит «всея Руси» Феодосий, благодаря чему А. Попов атрибутировал СИЛ 1461-м г.

Летописная версия антифлорентийского цикла начинает фиксироваться с конца XV в. Московский летописный свод стал образцом для последующего летописания. Под 1437 г. компилятор использовал СИЛ для передачи истории Восьмого собора, оставив в стороне панегирические фрагменты, посвященные православию и великому князю. Составитель значительно сократил первоначальный текст, сохранив послание митрополита Исидора пастве из Буды и письмо папы Евгения, обращенное к Василию Васильевичу ${ }^{40}$. Сокращенные версии антифлорентийского трактата фиксируются также в некоторых других летописях ${ }^{41}$.

В Иоасафовской летописи с небольшими изменениями повторяется версия, прозвучавшая в Московском своде. Компилятор при составлении своего текста, как нам кажется, мог опираться также на СИЛ. Григорий Болгарин тут назван Цамблаком ${ }^{42}$. На текст Иоасафовской летописи опирается также составитель Никоновского свода. Сам антифлорентийский памфлет тут разделен на отдельные части вставками обширных сообщений о внутренней и внешней политике Московии. Среди дополнений в сам текст памфлета - информация о заключении унийного договора, сообщение о приезде Исидора в Киев, добавлено также сообщение о великом князе, который единственный смог «разглядеть» в Исидоре «еретика», и только потом иерархи начали искать подтверждения «измены» митрополита. Используется также распространенная легенда о Петре Гугнивом, будто бы

37. А. Попов, Историко-литературный обзор..., с. 178-188.

38. Там же, с. 125-131.

39. Там же, с. 47-50.

40. Ср.: «Московский летописный свод конца XV века», ПСРЛ, т. 49, с. 257-261; «Слово избрано от святых писаний, еже на латыню», в: А. Попов, Историколитературный обзор..., с. 371-375.

41. См.: «Владимирский летописец», ПСРЛ, т. 3, с. 133; «Никаноровская летопись», ПСРЛ, т. 27, с. 106-107, 115, 271; «Вологодско-Пермская летопись», ПСРЛ, т. 26, c. $192,194,208,231$.

42. Иосафовская летопись, под. ред. А. А. Зимина, М., 1967, с. 19-20. 
извратившем православие в Риме ${ }^{43}$. Близкой к версии Московского свода является также версия в Симеоновской летописи (разночтения фиксируются лишь в начале статьи об унии $)^{44}$. Антифлорентийский памфлет в Воскресенской летописи ${ }^{45}$, основанный на Московской летописи 1526 г., мало чем отличается от Московского свода. Отдельные фрагменты рассказа перерываются интерполяциями о внутренних событиях, не связанных непосредственно с унией. Нарративной канвы Московского свода придерживаются также составители Львовской ${ }^{46}$ и Софиевской $\mathrm{II}^{47}$ летописей. Существенным дополнением в них является лишь включение письма великого князя к византийскому императору ${ }^{48}$, дублирующего рассказ о «еретике» Исидоре и правомочности поставления нового митрополита, т.к. Иона был предварительно, еще перед Исидором, номинирован на кафедру. Как и в СИЛ цитируется предложение короля Казимира о поставлении на митрополию Григория Болгарина после смерти Ионы. Цитируется также запрещение Ионой принимать благословение от ставленника Апостольской столицы, что привело к фактическому расколу митрополии ${ }^{49}$.

В Степенной книге (далее - СК) присутствуют две антифлорентийские статьи, меньшие по объему по сравнению с вышерассмотренными летописными. Первоисточником компилятору послужил Никоновский свод. В отличие от летописных версий, текст СК содержит вставку о мучениях восточных участников собора, не хотевших поддержать унию; рассказывается также о смерти императора Иоанна: после смерти земля не хотела принимать тело покойника, вывергая его три раза, после чего оно было съедено собаками ${ }^{50}$. Второй вариант антифлорентийского памфлета в CK без существенных изменений повторяет первый. Изменения: после возвращения Исидора в Москву великий князь и богословы вместе осудили митрополита-«предателя»; Иона еще до выборов был номинирован императором на митрополию. Компилятор указывает, что Константинополь боролся с мусульманами и болгарами до тех пор, пока сохранял верность православию, и только с принятием унии пошатнулась мощь империи ${ }^{51}$.

43. «Никоновская летопись», ПСРЛ, т. 9-14, с. 32-41. Подробнее о бытовании легенды о Петре Гугнивом в нарративных источниках XV-XVII вв.: В. Зема, «Візія розколу Церкви в ранній православній полеміці», Ковчег: Науковий збірник із церковної історій, ч. 3, Львів, 2001, с. 182-209.

44. «Симеоновская летопись», ПСРЛ, т. 18, с. 176.

45. «Воскресенская летопись», ПСРЛ, т. 8, с. 100-109.

46. «Львовская летопись», ПСРЛ, т. 20, с. 251-254.

47. «Софиевская вторая», ПСРЛ, т. 6, ч. 2, 92-97.

48. Ср.: «Послание великого князя Василия Васильевича к греческому царю Константину Палеологу о поставлении митрополита Ионы», Памятники древнерусского канонического права, ч. І, СПб., 1880, стб. 583.

49. «Софиевская вторая», с. 101-102; «Львовская летопись», с. 256.

50. «Степенная книга царского родословия», ПСРЛ, т. 21, с. 460-463.

51. Там же, с. 506-512. 
В летописные версии антифлорентийских памфлетов активно включались источники актового характера, большинство из которых вызывали сомнения у исследователей. Среди них: письмо папы Евгения IV великому князю, неизвестное по греческим и латинским источникам; письмо Исидора к христианам Великого княжества Литовского и Речи Посполитой, Священной Римской империи и Руси; два письма московских князей в Константинополь; письмо «Апология Марка Евгеника». Как указывает А. Плигузов, послание патриарху Митрофану о праве поставления митрополита без предварительного благословения в Константинополе, как и послание 1441 г., легендарные по своей сути, могут считаться протографами СИЛ. Плигузов считает, что письмо прота Афонских монастырей Пахомия, в котором он обращается к православным властителям, как и письмо Василия Васильевича, следует также считать апокрифами, чему возражает C. Н. Кистерев ${ }^{52}$. Относительно околичного послания восточных патриархов с отказом от унии, то хоть оно, как считает Плигузов, и известно в греческом варианте, однако было составлено с целью подтверждения правильности позиции московского князя ${ }^{53}$.

Короткий обзор антифлорентийских текстов позволяет нам предложить стемму текстологической взаимозависимости антифлорентийских источников. Мы предполагаем, что существовал некий гипотетический первоначальный текст $\alpha$, связанный с именем Симеона Суздальского. Эта версия была положена в основу ПСС (Муз.). Гипотетическая семья $\alpha$ дала начало семье $\beta$, которая, как можно предполагать, послужила основой текстов ЖСР и ИСС. Последний, в свою очередь, использовался компилятором СИЛ, от которого берет начало летописная версия. Версия антифлорентийского памфлета, представленная в Никоновской летописи стала канвой для создания соответствующих статей в СК. Гипотетический текст семьи $\gamma$ послужил основой для Холмогорской летописной версии ПСС, а также ПСС (Архивн.). Интерполирование актовых источников, в том числе апокрифического характера, можно считать свидетельством роста доверия и уважения к официальному делопроизводству. Изучение комплекса антифлорентийской полемики показывает, насколько свободно московские книжники оперировали своими источниками. На протяжении создания текстов антифлорентийского цикла значительному изменению в них подвергалась роль великого князя. Если в текстах, хронологически близких ко времени заключения унии, Василий Васильевич относился к проведению Вселенского собора скорее нейтрально, то позднее утвердилась совершенно иная версия событий и роль князя в этом процессе. Он стал рассматриваться как хранитель православия. Изменяется также роль Ионы как первого автокефального митрополита, культ которого был особо важен во времена создания патриархата. Он входит в т.н. «комплект святых» Уложенной

52. С. Н. Кистерев, «Источники о пребывании рязанского епископа Ионы в Константинополе», Россия и Христианский Восток, с. 62-63.

53. А. Плигузов, указ. соч., с. 516-526. 
грамоты 1589 г. вместе с митрополитом Петром, перенесшим свою резиденцию в Москву, и Алексием, поддерживавшим московскую государственную политику в XIV в. ${ }^{54}$

Проведенные нами исследования могут рассматриваться только как предварительные, перед более глубоким изучением всех памятников, отражающих восприятие Флорентийской унии в Московии, а также разъединительные тенденции на территории Киевской митрополии в XV в. Современная историография восприятия Флорентийской унии в Московии и Литве полна контроверсий. Поэтому необходимым является обращение к рукописным сборникам, содержащим тексты, связанные с Вселенским собором. Кодикографическое и палеографическое их исследование, воссоздание географии распространения этих памятников, цели и места их создания - представят картину «работы» московских книжников над созданием антифлорентийского комплекса. Безусловно, что весь комплекс памятников является лишь верхней частью айсберга, под которым скрываются политические и церковные отношения на территории Восточной Европы в XV-XVI вв. Сопоставление сообщений нарративных источников, совмещенное с реконструкцией исторических событий, поможет выработать новое понимание этой страницы в прошлом России.

Stemma codicum

Генеалогия антифлорентийских текстов

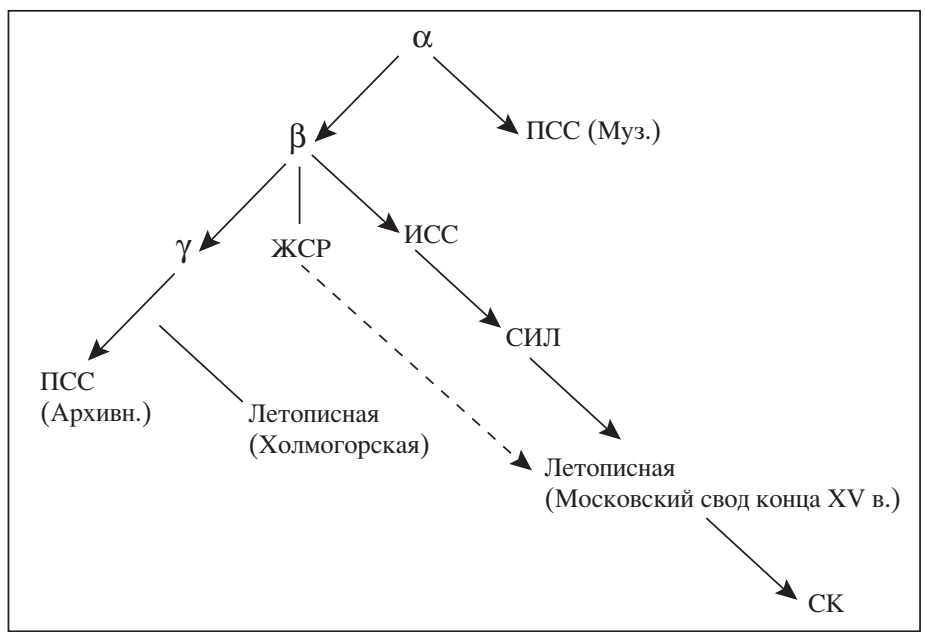

Национальная Академия Наук Украины

Институт истории Украинь

Киев

zema11@mailcity.com

54. D. Ostrowski, «A Muscovite Saint Set and Iona the Intruder», Russia Mediaevalis, t. X, 1, München, 2001, S. 150. 